\title{
Racial differences in a high-risk colorectal cancer referral population: a single-center experience
}

\author{
Cassandra Gulden $\mathrm{MS}^{1 *}$, Tovah Moss BA², Olufunmilayo I Olopade MD¹, Sonia Kupfer MD ${ }^{1,2}$ \\ From 14th Annual Meeting of the Collaborative Group of the Americas on Inherited Colorectal Cancer \\ Dallas, TX, USA. 12-13 October 2010
}

\section{Background}

Multiple studies have shown that colorectal cancer (CRC) disparities exist between African Americans and Caucasians. African Americans have higher CRC incidence and mortality than Caucasians [1,2]. Furthermore, African Americans present with more advanced CRC [3] and at younger ages [4]. However, little is known about the impact of hereditary CRC syndromes in African Americans on these disparities. In the University of Chicago Cancer Risk Clinic, we see a diverse referral population for evaluation of hereditary syndromes based on personal or family history of CRC. We sought to compare clinical characteristics of our African American and Caucasian patients to determine if differences exist in a high-risk CRC referral population.

\section{Method}

We retrospectively collected data on self-reported African American and Caucasian individuals who were referred for a personal or family history of CRC from 1992-2010. Available clinical characteristics including number of individuals, number of families (probands with family members who followed-up in our clinic), personal or family history of CRC, age at cancer onset, and number of individuals who underwent genetic testing for $A P C$ or mismatch repair genes were collected. Pedigrees were reviewed to determine Revised Bethesda, Amsterdam II and PREMM1,2 scores. Statistical analysis included Student's t-test for continuous variables and Pearson's chi-square for categorical variables. Comparison of independent proportions was done using z-ratios.

\section{Results}

A total of 949 Caucasian and 254 African American individuals were referred to the Cancer Risk Clinic for a personal or family history of CRC. The average age of CRC diagnosis, number of family members with CRC, and those meeting Bethesda and Amsterdam criteria were similar between populations (Table 1). Fewer family members of African American probands were seen compared to Caucasians ( $p=0.002$ ). More African American females with CRC were seen in our clinic $(\mathrm{p}=0.04)$. Importantly, despite overall similar clinical characteristics, fewer African Americans had genetic testing compared to Caucasians $(\mathrm{p}=0.02)$.

\section{Conclusion}

Despite many similarities between our high-risk CRC populations, there exists a difference in the number of family members of African American probands seen in our clinic and the number of African Americans who had genetic testing when compared to Caucasians. Less genetic testing may mean African American mutation carriers are not being identified. This can significantly impact appropriate cancer screening recommendations and knowledge about hereditary CRC syndromes in this population. Future collaborative studies are needed to address why these differences may exist.

\footnotetext{
Author details

${ }^{1}$ Cancer Risk Clinic, Section of Hematology/Oncology, University of Chicago Medical Center, Chicago, IL, 60637, USA. Section of Gastroenterology, University of Chicago Medical Center, Chicago, IL, 60637, USA.
}

\footnotetext{
* Correspondence: cgulden@medicine.bsd.uchicago.edu

'Cancer Risk Clinic, Section of Hematology/Oncology, University of Chicago Medical Center, Chicago, IL, 60637, USA

Full list of author information is available at the end of the article
} 
Table 1 Clinical characteristics of individuals referred for personal and/or family history of CRC by race

\begin{tabular}{|c|c|c|c|}
\hline & AA & Caucasian & p-value \\
\hline \multicolumn{4}{|l|}{ Personal and/or family history of CRC } \\
\hline Total number of individuals & 254 & 949 & \\
\hline Total number families (\% of total individuals) & $68(26.8)$ & $617(65.0)$ & 0.002 \\
\hline Median \# CRC affected family members (range) & $1(1-7)$ & $1(1-14)$ & \\
\hline Average number CRC affected family members $<50$ years & 0.35 & 0.46 & \\
\hline Number with polyps (\%) & $6(2.4)$ & $43(4.5)$ & 0.12 \\
\hline Genetic testing (\%) & $16(6.3)$ & $106(11.2)$ & 0.02 \\
\hline \multicolumn{4}{|l|}{ Personal History of CRC } \\
\hline Total number (\% of total) & $32(12.6)$ & $86(9.1)$ & 0.09 \\
\hline Age years (mean) & 48.6 & 49.9 & 0.65 \\
\hline$\%$ female & 82.1 & 60.5 & 0.04 \\
\hline Revised Bethesda + (\%) & $22(68.8)$ & $49(57.0)$ & 0.25 \\
\hline Amsterdam II + (\%) & $5(15.6)$ & $17(19.8)$ & 0.61 \\
\hline PREMM1,2 score & 17.06 & 16.12 & 0.81 \\
\hline Genetic testing (\%) & $10(31.2)$ & $42(48.8)$ & 0.09 \\
\hline
\end{tabular}

CRC, colorectal cancer; AA, African American; Genetic testing category includes mismatch repair genes and APC; PREMM1,2 score obtained using publicly available calculator.

Published: 10 March 2011

\section{References}

1. Jemal A, Siegel R, Ward E, Hao Y, Xu J, Murray T, Thun MJ: Cancer statistics, 2008. CA Cancer J Clin 2008, 58:71-96.

2. Matanoski G, Tao XG, Almon L, Adada AA, Davies-Cole JO: Demographics and tumor characteristics of colorectal cancers in the United States, 1998-2001. Cancer 2006, 71:3819-3826.

3. Doubeni CA, Field TS, Buist DS, Korner EJ, Bigelow C, Lamerato L, Herrinton L, Quinn VP, Hart G, Hornbrook MC, Gurwitz JH, Wagner EH: Racial differences in tumor stage and survival for colorectal cancer in an insured population. Cancer 2007, 109:612-620.

4. Fairley TL, Cardinez CJ, Martin J, Alley L, Friedman C, Edwards B, Jamison P: Colorectal cancer in U.S. adults younger than 50 years of age, 19982001. Cancer 2006, 107:1153-1161.

doi:10.1186/1897-4287-9-S1-P15

Cite this article as: Gulden et al:: Racial differences in a high-risk colorectal cancer referral population: a single-center experience. Hereditary Cancer in Clinical Practice 2011 9(Suppl 1):P15.

\section{Submit your next manuscript to BioMed Central} and take full advantage of:

- Convenient online submission

- Thorough peer review

- No space constraints or color figure charges

- Immediate publication on acceptance

- Inclusion in PubMed, CAS, Scopus and Google Scholar

- Research which is freely available for redistribution

Submit your manuscript at www.biomedcentral.com/submit
C Biomed Central 